\title{
Classes and Agrarian Transition in Pakistan
}

\author{
MAHMOOD HASAN KHAN*
}

This is a study of class formation and agrarian transition in Pakistan. The process of class differentiation under way is a manifestation of capitalist development. The agrarian transition in Pakistan is reflected by the disintegration of the peasant and feudal systems. The approach adopted in this paper demystifies the process of agricultural development in an underdeveloped country where, with the expansion of forces of production, the precapitalist relations of production are slowly dissolving. It should also help in discovering the mechanism by which agricultural surplus is extracted from direct producers and rural poverty is perpetuated.

\section{INTRODUCTION}

The historical role of agriculture in the process of capitalist development is well known: it provides surpluses of output and manpower for initiating industrialization. Development is initially fuelled by increased agricultural productivity and transfer of surplus for profits and capital accumulation. ${ }^{1}$ Rapid development of the forces of production in agriculture is then the most important task for the underdeveloped countries. It is also true that as the forces of production develop they bring about changes in the (social) relations of production. In a predominantly rural society, the

* The author is Professor in the Department of Economics, Simon Fraser University, Canada. This paper is based on two lectures he gave at the Pakistan Institute of Development Economics. He is grateful to Professor Syed Nawab Haider Naqvi for several valuable suggestions and comments. He thanks the Literary Editor of the PDR for stylistic improvements in the text. Of course, they bear no responsibility for the author's opinions and mistakes.

${ }^{1}$ This is expected of agriculture irrespective of the development paradigm one prefers or adopts. Industrialization (development) means creation and transfer of agricultural surplus produced by peasants and appropriated by either landlords or the state - to industries in the hands of capitalists or the state. But this is not all. In the contemporary debate on "unequal exchange" between the underdeveloped and developed (capitalist) countries, backwardness of agriculture in the former is seen as a major source of net transfer of the surplus through trade to the latter. It has been argued that low levels of productivity in agriculture, particularly in the food sector, result in international inequality of wages for labour of equal value. However, Emmanuel [12] and Lewis [32] present two different interpretations of the notion of "unequal exchange". 
agrarian structure undergoes a process of (class) differentiation, in which are embedded the seeds of uneven development. A study of the nature and direction of the process of (capitalist) development in an underdeveloped country should therefore highlight the process of class formation and agrarian transition.

In this study, we propose to study the nature and evolution of the agrarian transition in Pakistan. The agrarian structure in Pakistan is highly differentiated, characterized by asymmetrical relations between direct producers and those who own and control the means of production (land and capital). The process of class differentiation under way in the agricultural sector is a manifestation of capitalist development, created by the market forces and technology, and supported by public policy. This differentiation is increasingly based on the acquisition of capital by capitalist farmers and exploitation of the landless and near-landless peasants. The agrarian transition in Pakistan is reflected by the disintegration of the peasant (family farms) and feudal (landlord-sharecropper) systems.

There are two related objectives of this study. First, we develop a typology of peasantry in Pakistan, using the unequal endowments of land and labour as the main criteria for class differentiation. Secondly, we analyse the process of agrarian transition toward a capitalist agriculture, with particular emphasis on the underlying forces hastening this process. The orthodox literature on agricultural development assumes $a$ priori voluntary contractual agreements (tenures) on land between profitmaximizing individuals. There is, however, a well-developed body of dissenting literature which emphasizes the social relations of production, in which the contractual arrangements are not symmetrical and hence the differentiation of classes among farmers or peasants. The development of agriculture, within a framework of private property in land, is then seen as a contradictory process in which the class antagonisms sharpen with the development of the forces of production. ${ }^{2}$ We subscribe to this latter point of view in understanding the agrarian transition in Pakistan.

Since at each stage in our argument we plan to use empirical evidence "facts" - we should point out here the problems we have encountered in making use of the available (official) data. The usual caveats about quality of almost all published and unpublished data apply in Pakistan as in any other underdeveloped country. Further, the decennial censuses of population and agriculture, and the periodic national surveys, provide no direct information on farm households on the basis of ownership and use of land. Then there are no satisfactory data or estimates of the number and status of the landless agricultural workers. Finally, we have not found, at least for our purposes, complete or consistent data for each of the four provinces of Pakistan, namely, the Punjab, Sind, the North-Western Frontier Province (N.W.F.P.), and Baluchistan. We have, therefore, generalised on the basis of the evidence mainly from the Punjab and Sind and occasionally from the N.W.F.P. It

${ }^{2}$ The first view reflects the classical paradigm and the second view is Marxian in its origin. should be noted that the Punjab and Sind, which constitute the Indus basin, contribute over 80 percent of the national agricultural output, and a vast majority of farms are also located in these provinces. ${ }^{3}$

\section{A TYPOLOGY OF CLASSES}

The neoclassical paradigm rests on a world-view in which the individual makes "free" and "independent" choices among alternatives for the "best" outcome in economic relations with other individuals. Development is then a market-adjustment process, in which the economy tends to move - guided by the "invisible hand" from one (Pareto optimal) equilibrium to the next at a higher level of welfare. It is within this framework that the various tenancy relations about land have been explained. However, such a theory has little, if any, explanation for the co-existence of a variety of production relations or tenurial arrangements in agriculture. It is still less adequate in explaining the dynamics of the agrarian transition. ${ }^{4}$

The alternative paradigm is based on the premise that the individual is neither completely independent nor free, but acts as a member of the group within a complex set of relationships: individual choices are made only within a social context. According to this point of view, the dialectical historical process provides probably the only satisfactory route in understanding the differentiation of peasantry (or class formation) and agrarian transition to capitalism. ${ }^{5}$

The concept of class formation is central to the understanding of the tendency of a pre-capitalist (feudal and peasant) agriculture to transform into a capitalist state. Class as a concept is embedded in the dichotomy between the ownership of means of production (land and capital) by some and the exploitation of the labour power of others (peasants and workers). It is an asymmetrical relationship, historically determined by the endogenous interaction of the forces of production and (social) relations of production. We use this dichotomy as a basis for identifying agrarian classes. $^{6}$ As shown in Chart 1 , there are at present five distinct classes in the agricultural sector of Pakistan. Their salient features need some explanation here.

${ }^{3}$ Landownership data have never been published as part of the agricultural censuses in Pakistan. They have not been available to researchers for reasons best known to officials responsible for land records, etc. Further, there are no definite land records for ownership in several areas of Baluchistan and "tribal" areas in the N.W.F.P. Finally, even the agricultural census data have serious problems for studying changes in operational holdings (farms), say, in the $1960 \mathrm{~s}$. Rerently, Hussain [20] has given details of the adjustments one would have to make to compare the farm data collected in the 1960 and 1972 agricultural censuses.

${ }^{4}$ Currie [9] provides a detailed treatment of various tenure systems within a neoclassical framework. We do not have a global optimum but only local ones, depending not only on the level of welfare postulated but also the specific segment.

${ }^{5}$ We have made use of the works of Lenin [31]; Kautsky; Hussain and Tribe [19, Chapte 4 in Volume I and Chapter 2 in Volume II] and Chayanov [see 30].

${ }^{6}$ It is somewhat similar to the method used by Bardhan [5]. 
differentiated agrarian economy. By the same token, it avoids many of the pitfalls inherent in empty categories based on either tenure or size, such as "landlords", "owner-operators", and "tenants" - a classification based on an arbitrary criterion of tenure - or "large", "medium" and "small" farmers - a classification based on an even more arbitrary criterion of farm size. The proposed scheme cuts across the simplistic tenure categories of lessors and lessees. Also, it does not maintain a direct relationship with large and small holdings. Lessors could be landlords or middle and poor peasants owning but not using land. Lessees could be capitalist farmers or sharecroppers and poor peasants supplementing their own holdings. Classifications based on arbitrary size and tenure categories do not reveal the production relations. Instead, they mystify the creation and appropriation of the social surplus. These groupings do not even assist in analysing the problems of farm organisation in relation to the issues of "efficiency" and "equity". Finally, the arbitrary classifications do not reveal the impact of extraction of agricultural surplus for capitalist accumulation on each of the classes.

What "facts" do we have about the proposed typology for classes in Pakistan's agriculture? In Table 1, we identify classes by quantifying their shares in total farm households. There are several interesting features. First, family farms (households) are preponderant in the N.W.F.P. and the Punjab. But just over one-quarter of the farm households are family farmers in Sind. Secondly, sharecropping (tenant) households dominate in Sind, but they have only one-quarter of the share of farm households in the other two provinces. Thirdly, capitalist households are most visible in the Punjab (27 percent), with their second largest concentration in Sind (21 percent). These households have less than 12 percent of share in the N.W.F.P. Finally, landlord households in all provinces taken together are just over one percent, but their relative dominance, particularly in Sind, is reflected in the high share of tenant (sharecropping) households in the economy.

There is another related aspect of these four classes in the three provinces. Family farmers seem to have control of holdings ranging from less than one acre to 25 acres. Those who are operating or owning less than one acre can be regarded as landless households, much like the landless workers available in the labour market in or outside agriculture. The share of these in all households in the N.W.F.P. is 12 percent, but they are apparently much more limited in the Punjab and almost non-existent in Sind. ${ }^{7}$ Most of the holdings in the range of $1-5$ and 5-12.5 acres are dominated by either family farmers, as in the N.W.F.P. and the Punjab, or sharecroppers, as in Sind. Capitalist households seem to cultivate in the range of $12.5-25.0$

${ }^{7}$ The number of households of landless workers is probably quite large in the provinces of Punjab and N.W.F.P., but we have no direct information in official data from censuses and surveys. Eckert [11]; Khan [24] and Naseem [38] give substantial evidence on the conditions of agricultural workers, including their wages, for several areas of the Punjab in the 1970 s.

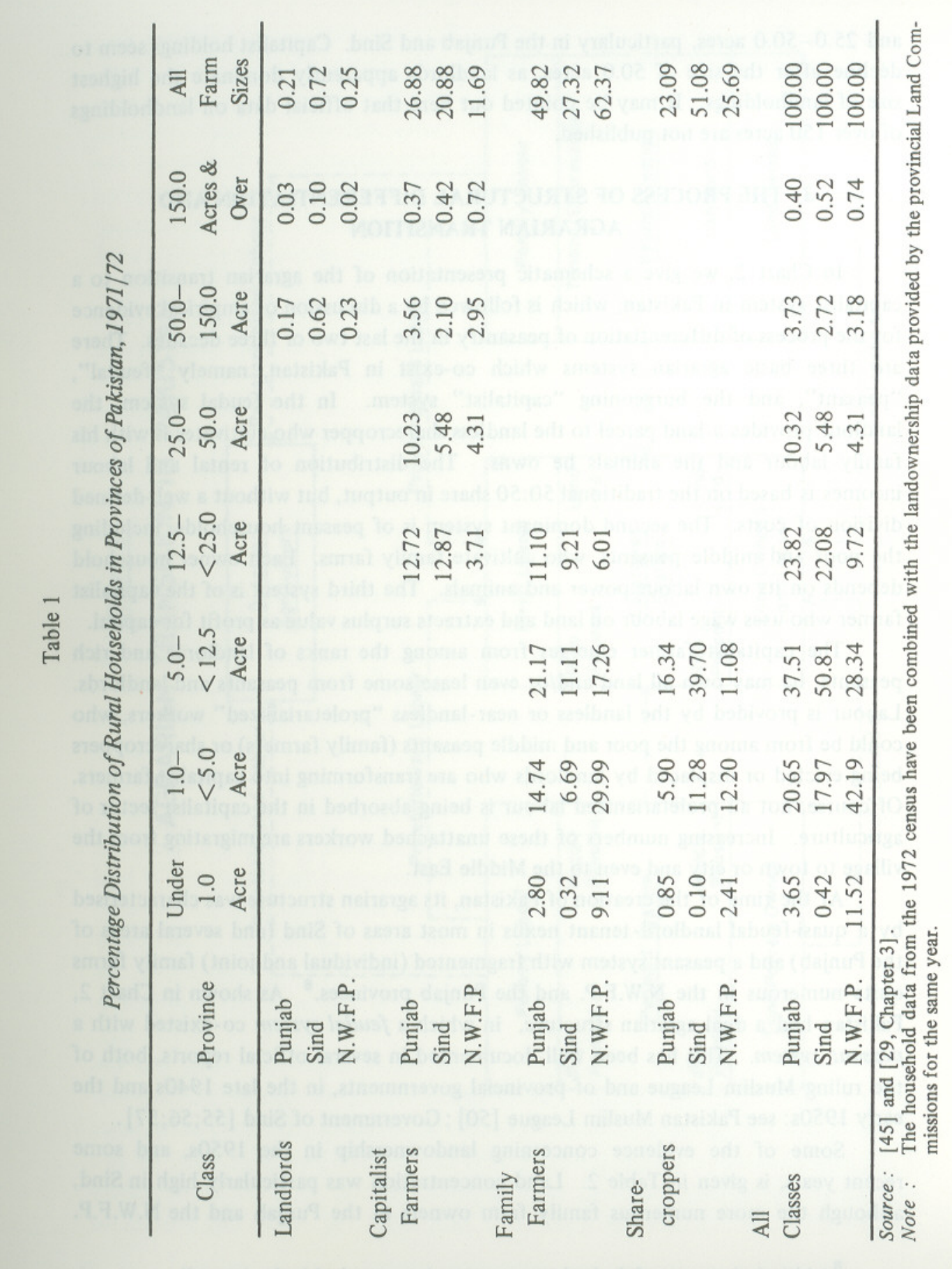


and 25.0-50.0 acres, particulary in the Punjab and Sind. Capitalist holdings seem to decline after the size of 50.0 acres, as landlords apparently dominate the highest size of landholdings. It may be pointed out here that official data on landholdings of over 150 acres are not published.

\section{THE PROCESS OF STRUCTURAL DIFFERENTIATION AND AGRARIAN TRANSITION}

In Chart 2, we give a schematic presentation of the agrarian transition to a capitalist system in Pakistan, which is followed by a discussion of empirical evidence for the process of differentiation of peasantry in the last two or three decades. There are three basic agrarian systems which co-exist in Pakistan, namely "feudal", "peasant", and the burgeoning "capitalist" system. In the feudal system, the landlord provides a land parcel to the landless sharecropper who cultivates it with his family labour and the animals he owns. The distribution of rental and labour incomes is based on the traditional 50:50 share in output, but without a well-defined division of costs. The second dominant system is of peasant households, including the poor and middle peasants, who cultivate family farms. Each owner household depends on its own labour power and animals. The third system is of the capitalist farmer who uses wage labour on land and extracts surplus value as profit for capital.

The capitalist farmer emerges from among the ranks of landlords and rich peasants: he may own all land and/or even lease some from peasants and landlords. Labour is provided by the landless or near-landless "proletarianized" workers, who could be from among the poor and middle peasants (family farmers) or sharecroppers being evicted or displaced by landlords who are transforming into capitalist farmers. Of course, not all proletarianized labour is being absorbed in the capitalist sector of agriculture. Increasing numbers of these unattached workers are migrating from the village to town or city and even to the Middle East.

At the time of the creation of Pakistan, its agrarian structure was characterised by a quasi-feudal landlord-tenant nexus in most areas of Sind (and several areas of the Punjab) and a peasant system with fragmented (individual and joint) family farms quite numerous in the N.W.F.P. and the Punjab provinces. ${ }^{8}$ As shown in Chart 2, Pakistan had a dual agrarian structure, in which a feudal system co-existed with a peasant system. This has been well documented in several official reports, both of the ruling Muslim League and of provincial governments, in the late 1940s and the early 1950s: see Pakistan Muslim League [50] ; Government of Sind [55;56;57].

Some of the evidence concerning landownership in the 1950s, and some recent years, is given in Table 2. Land concentration was particularly high in Sind, although the more numerous family farm owners in the Punjab and the N.W.F.P.

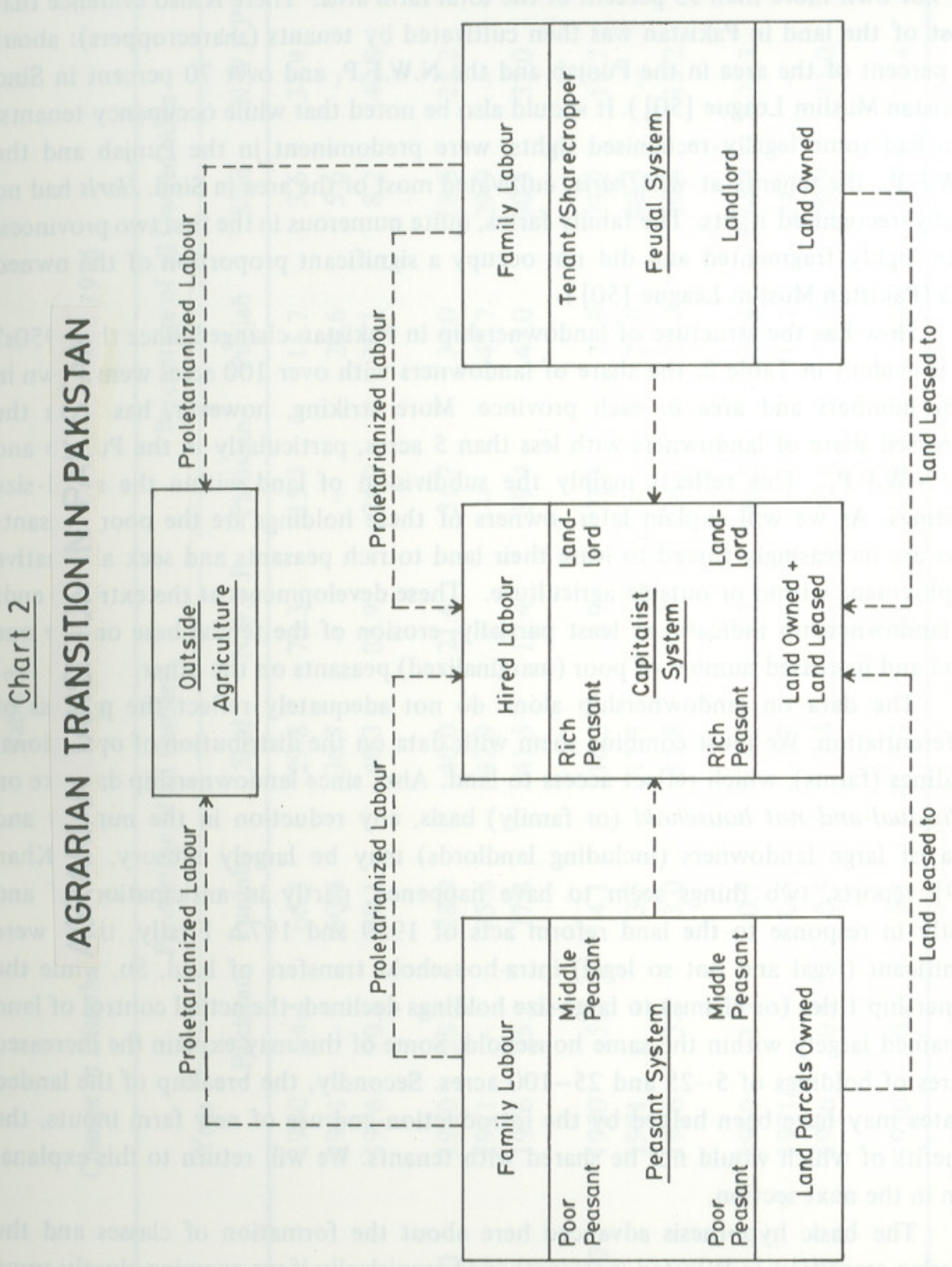

${ }^{8} \mathrm{~A}$ historical account of the land tenure system is summarised in the Appendix. 
did not own more than 55 percent of the total farm area. There is also evidence that most of the land in Pakistan was then cultivated by tenants (sharecroppers): about 50 percent of the area in the Punjab and the N.W.F.P. and over 70 percent in Sind (Pakistan Muslim League [50] ). It should also be noted that while occupancy tenants, who had some legally-recognised rights, were predominent in the Punjab and the N.W.F.P., the tenants-at-will (haris) cultivated most of the area in Sind. Haris had no legally-recognised rights. The family farms, quite numerous in the first two provinces, were highly fragmented and did not occupy a significant proportion of the owned area (Pakistan Muslim League [50]).

How has the structure of landownership in Pakistan changed since the 1950s? As is evident in Table 2, the share of landowners with over 100 acres went down in their numbers and area in each province. More striking, however, has been the increased share of landowners with less than 5 acres, particularly in the Punjab and the N.W.F.P. This reflects mainly the subdivision of land within the small-size holdings. As we will explain later, owners of these holdings are the poor peasants who are increasingly forced to lease their land to rich peasants and seek alternative employment within or outside agriculture. These developments at the extreme ends of landownership indicate, at least partially, erosion of the feudal base on the one hand and increased number of poor (marginalized) peasants on the other.

The data on landownership alone do not adequately reflect the process of differentiation. We must combine them with data on the distribution of operational holdings (farms), which reflect access to land. Also, since landownership data are on individual and not household (or family) basis, any reduction in the number and area of large landowners (including landlords) may be largely illusory. As Khan [29] reports, two things seem to have happened, partly in anticipation of and partly in response to the land reform acts of 1959 and 1972. Firstly, there were significant (legal and not so legal) intra-household transfers of land. So, while the ownership titles (or claims) to large-size holdings declined, the actual control of land remained largely within the same household. Some of this may explain the increased shares of holdings of 5-25 and 25-100 acres. Secondly, the breakup of the landed estates may have been helped by the introduction and use of new farm inputs, the benefits of which would not be shared with tenants. We will return to this explanation in the next section.

The basic hypothesis advanced here about the formation of classes and the agrarian transition in Pakistan is strengthened empirically if we examine closely some of the evidence of the use of land together with its ownership. Some of this evidence is provided directly by the agricultural census data on distribution of farms by size and tenure. When combined with data on landownership they can even indicate changes in the production relations, i.e. a shift from the feudal and peasant to

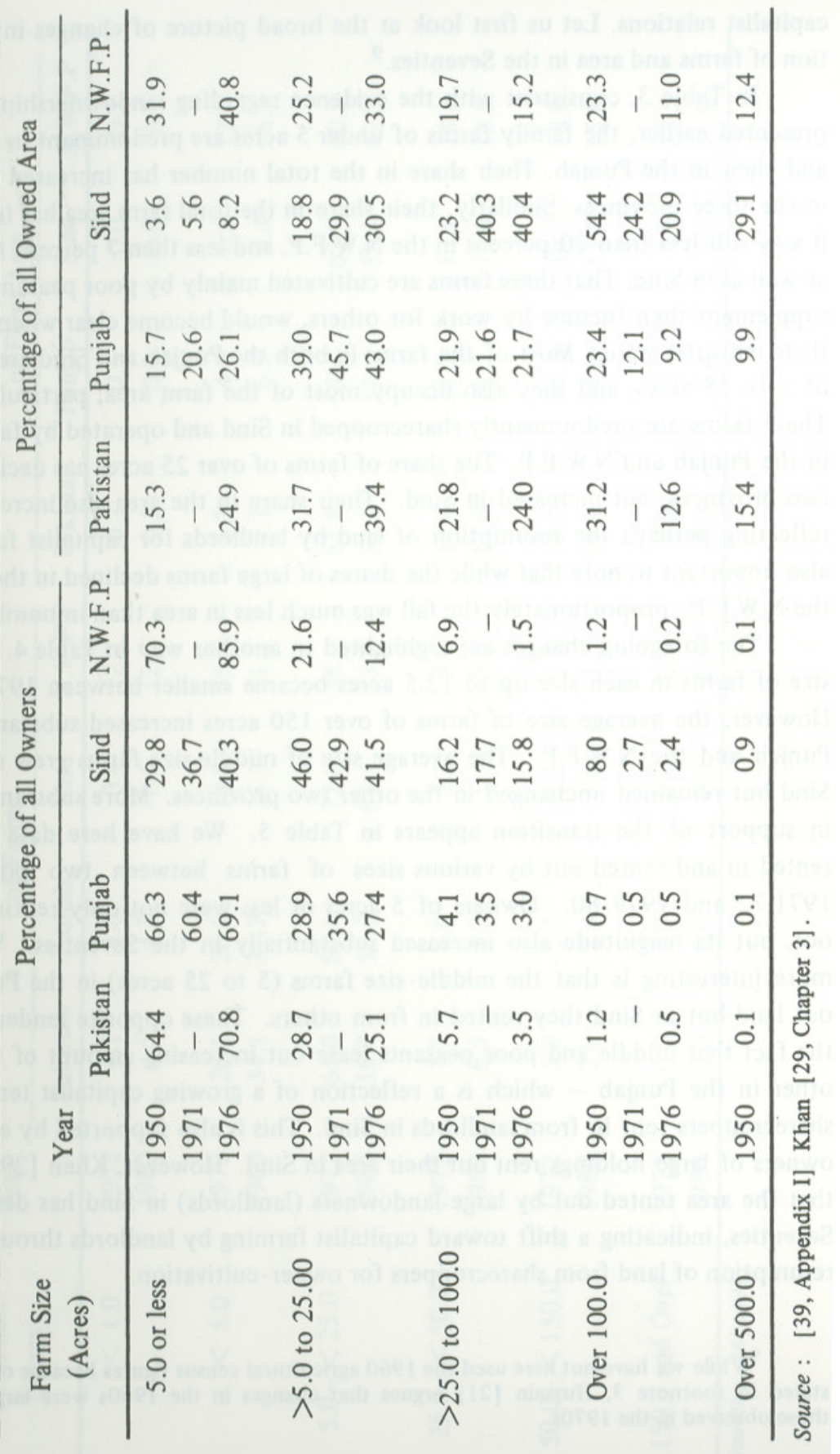


capitalist relations. Let us first look at the broad picture of changes in the distribution of farms and area in the Seventies. ${ }^{9}$

In Table 3, consistent with the evidence regarding landownership by farm size presented earlier, the family farms of under 5 acres are predominant in the N.W.F.P. and then in the Punjab. Their share in the total number has increased substantially in the three provinces. Similarly, their share in the total farm area has increased, but it was still less than 20 percent in the N.W.F.P. and less than 7 percent in the Punjab as well as in Sind. That these farms are cultivated mainly by poor peasants, who must supplement their income by work for others, would become clear when we examine their tenturial status. Most of the farms in both the Punjab and Sind are in the range of 5 to 25 acres, and they also occupy most of the farm area, particularly in Sind. These farms are predominantly sharecropped in Sind and operated by family farmers in the Punjab and N.W.F.P. The share of farms of over 25 acres has declined in these two provinces, but increased in Sind. Their share in the area also increased in Sind, reflecting perhaps the resumption of land by landlords for capitalist farming. It is also important to note that while the shares of large farms declined in the Punjab and the N.W.F.P., proportionately the fall was much less in area than in numbers.

The foregoing changes are highlighted in another way in Table 4. The average size of farms in each size up to 12.5 acres became smaller between 1972 and 1980 . However, the average size of farms of over 150 acres increased substantially in the Punjab and the N.W.F.P. The average size of middle-size farms grew somewhat in Sind but remained unchanged in the other two provinces. More substantial evidence in support of the transition appears in Table 5. We have here data on the area rented in and rented out by various sizes of farms between two points in time: 1971-72 and 1979-80. Owners of 5 acres or less were not only renting their area out, but its magnitude also increased substantially in the Seventies. What is even more interesting is that the middle-size farms ( 5 to 25 acres) in the Punjab rented out land but in Sind they rented in from others. These opposite tendencies explain the fact that middle and poor peasants lease out increasing amount of their land to other in the Punjab - which is a reflection of a growing capitalist tenancy - and sharecroppers rent in from landlords in Sind. This is also supported by evidence that owners of large holdings rent out their area in Sind. However, Khan [29] has shown that the area rented out by large landowners (landlords) in Sind has declined in the Seventies, indicating a shift toward capitalist farming by landlords through increased resumption of land from sharecroppers for owner-cultivation.

${ }^{9}$ While we have not here used the 1960 agricultural census figures because of the problems stated in footnote 3 , Hussain [21] argues that changes in the 1960 s were largely similar to those observed in the 1970 s.

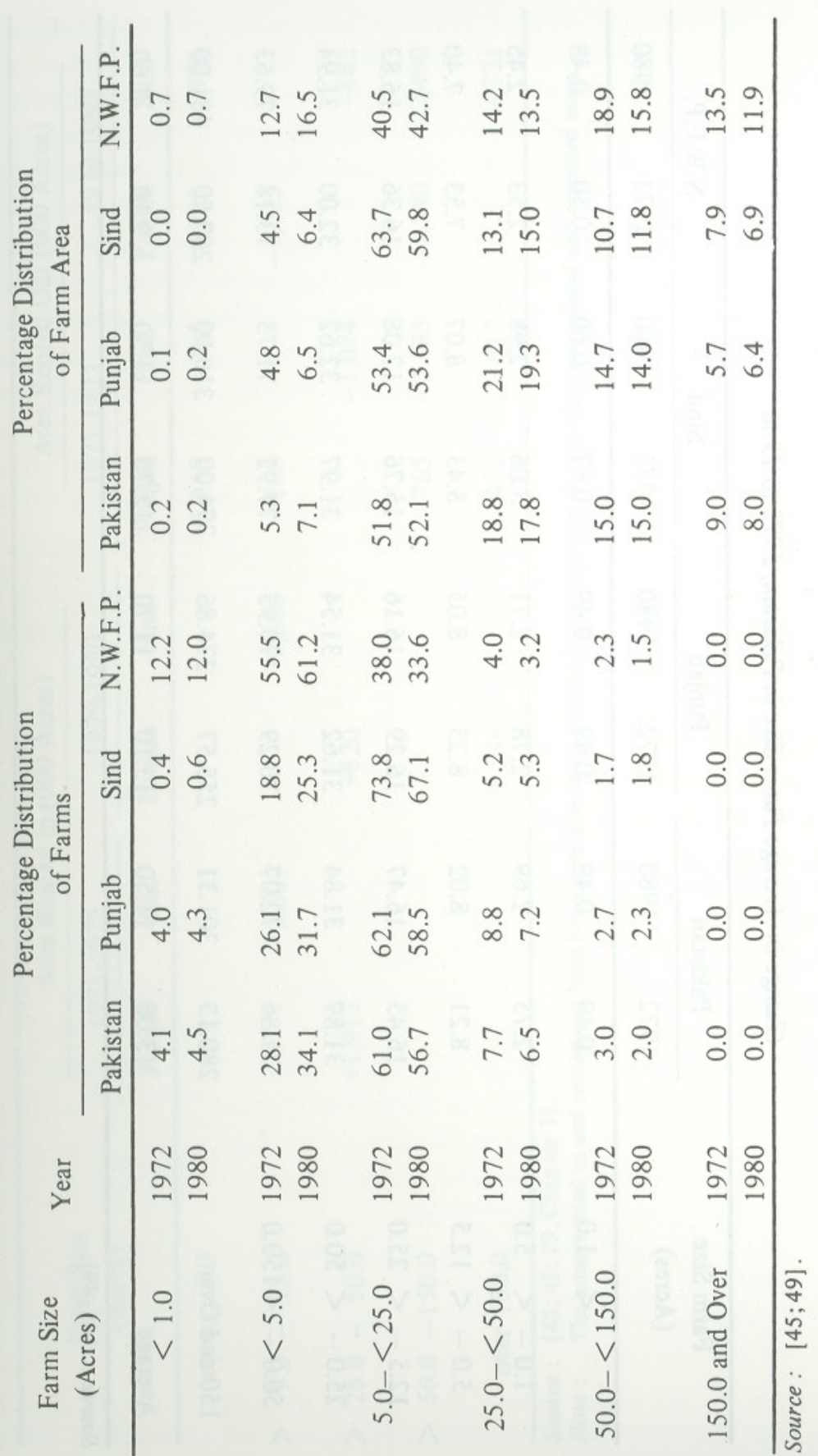


Change in Average Farm Size in Pakistan, 1972 to 1980

\begin{tabular}{|c|c|c|c|c|c|c|c|c|}
\hline \multirow{2}{*}{$\begin{array}{c}\text { Farm Size } \\
\text { (Acres) }\end{array}$} & \multicolumn{2}{|c|}{ Pakistan } & \multicolumn{2}{|c|}{ Punjab } & \multicolumn{2}{|c|}{ Sind } & \multicolumn{2}{|c|}{ N.W.F.P. } \\
\hline & 1972 & 1980 & 1972 & 1980 & 1972 & 1980 & 1972 & 1980 \\
\hline$<1.0$ & 0.49 & 0.49 & 0.49 & 0.49 & 0.67 & 0.60 & 0.50 & 0.48 \\
\hline $1.0-<5.0$ & 2.75 & 2.69 & 2.78 & 2.71 & 3.06 & 2.98 & 2.53 & 2.45 \\
\hline $5.0-<12.5$ & 8.21 & 8.02 & 8.23 & 8.05 & 8.43 & 8.07 & 7.53 & 7.40 \\
\hline $12.5-<25.0$ & 16.45 & 16.47 & 16.29 & 16.16 & 16.76 & 17.08 & 16.36 & 16.83 \\
\hline $25.0-<50.0$ & 31.89 & 31.84 & 31.62 & 31.54 & 31.97 & 32.62 & 32.00 & 31.94 \\
\hline $50.0-<150.0$ & 71.86 & 72.07 & 70.29 & 70.95 & 77.92 & 71.73 & 73.18 & 79.63 \\
\hline 150 and Over & 280.13 & 301.31 & 255.57 & 274.86 & 374.00 & 316.00 & 287.50 & 481.00 \\
\hline Average & 13.00 & 11.50 & 13.10 & 11.70 & 12.70 & 11.50 & 9.10 & 7.60 \\
\hline
\end{tabular}

Source: $[45 ; 49]$.

Table 5

Renting of Farm Area by Size of Holding in Provinces of Punjab and Sind, 1971-72 and 1979-80

\begin{tabular}{|c|c|c|c|c|c|c|c|c|c|}
\hline & \multirow{3}{*}{$\begin{array}{c}\text { Farm Size } \\
\text { (Acres) }\end{array}$} & \multicolumn{4}{|c|}{ Area Rented in (000 Acres) } & \multicolumn{4}{|c|}{ Area Rented Out (000 Acres) } \\
\hline & & \multicolumn{2}{|c|}{$1971-1972$} & \multicolumn{2}{|c|}{$1979-1980$} & \multicolumn{2}{|c|}{$1971-1972$} & \multicolumn{2}{|c|}{$1979-1980$} \\
\hline & & Punjab & Sind & Punjab & Sind & Punjab & Sind & Punjab & Sind \\
\hline & up to 5.0 & & & & & $-5,985$ & -218 & $-8,280$ & -372 \\
\hline$>$ & $5.0-25.0$ & & $+2,607$ & & $+1,856$ & -165 & & $-1,023$ & \\
\hline$>$ & $25.0-50.0$ & $+1,917$ & & +820 & & & $-1,074$ & & -882 \\
\hline$>$ & $50.0-150.0$ & & & & & -765 & $-2,383$ & $-1,540$ & $-2,490$ \\
\hline & over 150.0 & & & +538 & & -432 & -917 & & -721 \\
\hline
\end{tabular}

Source: $[45 ; 49 ; 29$, Chapter 3$]$.

Note: The areas rented in and rented out have been determined by differences in each size of farm between owned and operated areas. 
In the Punjab, most of the land rented out by poor and middle peasants is leased by rich peasants, particularly those with 25 to 50 acres and some of it even by farmers with 150 acres and more. In fact, this tendency of the very large farms to increase in size was also reflected in Table 4: the average size of farms of over 150 acres increased substantially in the Seventies. These changes in renting or leasing of land between various sizes of farms indicate that (a) poor peasants are increasingly renting out their lands to middle and rich peasants, (b) landlords are renting out less land to sharecroppers, and (c) capitalist farms are increasing at the expense of poor (and even middle) peasants in the Punjab and of landlords (and their sharecroppers) in Sind. Khan [29] and Hussain [21] have provided supporting evidence of changes in owner-operated and sharecropped areas in the country in the Sixties and Seventies.

\section{SOME EXPLANATIONS OF THE AGRARIAN TRANSITION}

The agricultural crisis of the 1950s in Pakistan has been well documented (Falcon and Gotsch [14]). Farm productivity stagnated and the rate of growth of population started to gather momentum. The agrarian structure remained highly differentiated, except that at the lower end of the peasantry there was increasing subdivision and fragmentation of holdings. The settlement of Muslim refugees from India, at least in the Punjab, added to the increasing number of middle and poor peasants. In Sind, it tended to aggravate the conditions of the haris, as most of the settled refugees joined the ranks of absentee landowners. The political environment for agrarian "reforms", so much publicized in the early days of Pakistan by the top leadership, remained unfavourable and the landed elite stayed intransigent. The tenancy reforms of the early 1950s in the provinces introduced some marginal changes for the occupancy and non-occupancy tenants [29].

The land reforms of 1959 brought the first visible pressure on landlords to readjust their holdings and relations with peasants. However, as Khan [29] has shown, there is ample evidence that these reforms did not basically alter the concentration of landownership, as there were substantial intra-family (or intrahousehold) land transfers and even evasion of the ceiling on individual holdings. The landless and near-landless peasants received little if any land, and most of the resumed land was in any case uncultivable. ${ }^{10}$

The most significant changes affecting the agrarian structure came with the development of water supply, particularly of ground water through installation of private tubewells in the Punjab. This facilitated the adoption of fertilizer and new

${ }^{10}$ See also the debate between Alavi [4] and Burki [8]. Khan [29] and Hussain [21] support Alavi's argument that these reforms did not reduce the influence of landlords on the
political process in the country. seed of wheat and rice in the latter part of the Sixties. Public policy of subsidies and price support played an important supportive role. However, it is equally important to note here that public policy at that stage was part of a "bimodal" strategy, emphasizing the dependence on large-scale and commercialized farming in contrast with a "unimodal" approach which emphasizes the growth of the entire agricultural sector. ${ }^{11}$

The bimodal strategy of agricultural growth, reflecting the dominant ideology and political alliances, has several interesting features. First, it prefers the adoption and use of technology which is not neutral to scale. Second, the increased private profitability of new inputs, created mainly by public subsidies, produces a double process: increasing capitalist relations on land and decreasing feudal tenancy, both at the expense of poor peasants and sharecroppers. Third, the availability and use of the productivity-increasing inputs are themselves a function of the social conditions in which they are introduced. It is, therefore, important that the underlying forces for the transition should be seen within the context of the agrarian structure itself.

The bimodal strategy was premised on two crucial assumptions. The first assumption was that the central task in the development process was to generate income through private markets, building on the best, which will also combine the trickle down effects. Secondly, it was assumed that the emerging biformity in the agrarian structure - the rich kulak type peasants (owners and operators of large farms) in the lead and the poor peasants (small owner-operators and sharecroppers) following - will both create a rapid process of growth and trickle the effects down to the mass of poor peasants. In short, dependence on large-scale farms was the cornerstone of the bimodal strategy as opposed to the unimodal approach followed by countries like Japan, Taiwan and South Korea in the 1950s. The bimodal strategy in Pakistan reflected partly the belief in the trickle-down theory, so popular at that time, and partly the reality of a biformed agrarian structure which was emerging in Pakistan after the land reforms of 1959.

Let us now examine the forces which can help to explain the agrarian transition under way in Pakistan. As earlier, we will use "facts" where the data permit.

\section{Changes in Productivity and} the Agrarian Transition

Private profitability depends on, among other things, the extent to which new (better) inputs lead to positive changes in the cropping pattern (e.g., multiple cropping) and level of yields of crops. Berry and Cline [6] have provided substantial evidence that farm productivity (technical efficiency) is closely related to the size of

${ }^{11}$ A full discussion of agricultural strategies in the sixties can be found in Johnston and 
farm and the tenurial arrangement. The traditional superiority enjoyed by small (owner-operated) farms was premised on their intensive use of family labour and animal power. However, with the spread of the Green Revolution technology in Pakistan, the size-efficiency relationship seems to have been reversed in favour of the large farms, thanks to the water-fertilizer-seed-machine package which the rich peasants and landlords could obtain at highly subsidized rates. ${ }^{12}$ The water-machine technology required lumpy investment and the technology package was not scaleneutral. The credit-extension services, with the input and output markets, have also been closely linked to the size of one's holdings. As we will argue later, the structure of technology and the direction of credit flows themselves reflected the influence of large landowners and capitalist farmers on public policy.

There has also been an equally impressive demonstration of the higher level of productivity of owner-operated (small) farms vis-a-vis sharecropped (small) farms in Pakistan. ${ }^{13}$ Landlords could appropriate entirely the benefits of new technology by reducing their dependence on sharecroppers. Resumption of land for "self-cultivaton" became not only profitable but also necessary: the increasing pressure of cash economy and the competition with rich peasants and capitalist farmers have narrowed the choices of landlords. Further, in those areas of the Punjab and Sind in which the cost of attached labour (sharecroppers) was rapidly rising, there was added incentive for landlords to adopt the machine technology and make use of the relatively cheap labour which these machines created among tenants and landless workers. The scale and management effects have become clearly dominant in determining the size and tenancy arrangements in Pakistan agriculture. Under the propitious conditions created by the new technology and supported by public policy, capitalist agriculture has become an increasingly attractive and even necessary alternative to the feudal and peasant systems. We should now turn to factors (inputs and policies) which have created the differential productivity effects in the first place.

\section{Use of Inputs and the Agrarian Transition}

Productive and commercialised agriculture develops with technological change, including new inputs and new methods of organising the old inputs. The introduction of new inputs and methods depends on a host of factors, of which the structure of landownership and tenurial arrangements are often the most important. The dominant feudal and the marginal peasant systems which Pakistan had inherited showed little propensity to change the age-old methods of production. Agricultural stagnation, in the face of rapid population growth, had created severe restraints on industrialization. It was against this background that the Ayub regime launched, in the

${ }^{12}$ We have now several studies in Pakistan, particularly in the Punjab and Sind, which support these generalisations. See, for example, Khan [26]; Mahmood [33] ; Salam [52]; Khan [27]; Mahmood and Haque [34].

${ }^{13}$ For example by Khan $[28 ; 29]$. For some other countries, see Berry and Cline [6]. early Sixties, its search for what were regarded as the most important inputs of factors for generating and sustaining agricultural growth. We should now analyse the effects of the new inputs and technology on the agrarian transition in Pakistan.

\section{Water Development}

In arid Pakistan, water has been rightly conceded as one of the most important inputs for crop growth. The canal irrigation system, inherited from the British administration and concentrated mainly in the plains of the Punjab and Sind, was quite inadequate to meet the water requirements of even the traditional cropping patterns. Further, water losses from the canal system were no less serious, partly because of poor drainage and partly owing to poor water management on the farm. Vast national resources were required to expand the surface irrigation system and to alleviate the menace of waterlogging and salinity. It was at this time that, at least in the plains of the Punjab, installation of private tubewells as a supplementary source of water became evidently profitable. As Ghulam Mohammad [36] shows, the development of private tubewells in the central and eastern districts of the Punjab had become impressive and its results quite as manifest by the mid-Sixties.

Private tubewells have provided additional water and at the time when it was most needed for optimum plant growth. New crops could now be grown, which required more water, and use of fertilizer became evidently profitable. It also then facilitated the adoption of high-yielding seeds of wheat and rice introduced in the late-Sixties. There are at least four important aspects of the development of private tubewells which should be highlighted here.

(1) Private tubewells have been installed mainly in the plains of the Punjab. They are not economical in mountainous areas because of the great depth to which they must be sunk to reach ground water. For similar reasons, they have not been developed in Sind where the high degree of salinity is an additional barrier. This uneven development of ground water has been an important factor in explaining some of the interregional disparities one observes in the country. ${ }^{14}$

14 Water from private tubewells has become a major source of irrigation to farms in several areas of the Punjab. The impressive increase in numbers of tubewells can be seen in the following:

$\begin{array}{cclrl}\begin{array}{c}\text { Year } \\ 1964-65\end{array} & \text { Pakistan } & & \text { Punjab } & \\ 1970-71 & 34,400 & \text { (private) } & 28,746 & \text { (private) } \\ 1974-75 & 97,636 & \text { (private + public) } & 81,814 & \text { (private) } \\ 1979-80 & 154,290 & \text { (private + public) } & 130,453 & \text { (private) } \\ & 185,973 & \text { (private + public) } & 154,468 & \text { (private) }\end{array}$

These figures are from Eckert [10]; Yasin [63]; Government of Pakistan [42]. 
(2) Private tubewells have been installed mostly by landowners with holdings of over 25 acres. Given the indivisible and large capacity of diesel and electric tubewells, even the middle peasants cannot afford their fixed and variable costs. Therefore, there has been a high concentration of ownership of tubewells. ${ }^{15}$ It has two associated problems. For one thing, while a market for tubewell water has evidently developed, it has not been easy for the non-owners (poor peasants) to buy water at reasonable rates and at the time when they need it most. This has created increased uncertainty, which acts against innovation. The other problem is that the concentration of tubewells has provided added incentive to large landowners (i.e., tubewell owners) to lease their neighbours' land, if not buy them out. Capitalist farming is thus facilitated by the increased size of operational holding (farm).

(3) Inducement to invest in tubewells has been provided by handsome public subsidies on fuels, installation costs and maintenance. In fact, these subsidies have become an important mechanism for transferring public tubewells - which were installed in the Indus basin to alleviate the problems of waterlogging and salinity - to private ownership. ${ }^{16}$

(4) Private ownership of tubewells has in no small measure been encouraged by a credit policy under which loans have been advanced through the Agricultural Development Bank of Pakistan (A.D.B.P.) [1]. The World Bank [61] document on the A.D.B.P. shows that these loans have been available not only readily, given the collateral of land, but also at very low rates of interest with convenient terms for repayment.

As stated earlier, substantial investment in surface-and ground-water supply has been made by various levels of governments, starting mainly in the late Fifties. Surface water has been available to users at highly subsidized rates: water revenues do not even cover the maintenance expense of the canal system in the public sector. However, access to canal water in the village is not without problems. The watercourse system is regulated by public officials inconsultation with "committees" of water users on each watercourse. Studies by the World Bank [62] and the USAID [59] have shown that tail-enders on a watercoruse, who are usually the middle and poor peasants, are always at a disadvantage in getting water in adequate quantity and when they need. This has been a serious handicap to innovation and higher level of income.

It is also be now well known that additional and assured supply of water has been a major factor in raising the private profitability of fertilizer and new seeds of wheat and rice in Pakistan. As a new (non-traditional) input, fertilizer was introduced with public subsidy, which remains even today an important component of

${ }^{15}$ This is clearly shown in the agricultural machinery census [46].

${ }^{16}$ Since 1980 the military government has been giving significant subsidies to farmers to buy public tubewells in all provinces. government policy for increasing crop output. However, use of fertilizer and new seeds, which in any case was premised on availability of adequate water supply, has not been without serious interregional and interfarm disparities. Dependence on rainfall, as in the rain-fed areas of the Punjab and the N.W.F.P. or inadequate canal water, as in the south-eastern parts of Sind, has been a major barrier to the use of fertilizer and new seeds, resulting in increased differences between the poor and rich peasants because of the unequal access to fertilizer and credit markets. Small peasants have clearly indicated that insufficient and uncertain supply of water and inadequate cash or credit militated against increasing the level of fertilizer per acre and coverage of the crop area $[13 ; 25]$. Cash/credit problem is aggravated by unequal access to the extension service, which is supposedly the carrier of applied knowledge about new technology.

\section{Tractorization}

The impact of mechanical inputs on growth and agrarian structure has been a centre of controversy in Pakistan. This applies particularly to the use of tractors, which have increased rapidly since the mid-Sixties. ${ }^{17}$ In general, the case for tractors is premised on the argument that they rationalize agriculture by their positive effect on (a) cropping intensity, (b) cost of human and animal labour, (c) yield level, and (d) land preparation and post-harvest operations. On the other hand, there are doubts about some of these positive effects, particularly on yield level and multiple cropping. More importantly, it has been contended that tractorization in Pakistan has resulted in (a) labour displacement and tenant eviction, and (b) expansion of holdings which are already large. Implied in these arguments is the notion that rich peasants and landlords are increasingly encroaching on lands which were available for cultivation to poor peasants and sharecroppers.

In the light of the available evidence, some generalisations can be made about tractors and their effects on growth and agrarian structure in Pakistan: see Govt. of Pakistan [43;44]; Bose and Clark [7]; Ahmad [2] ; Gotsch [15] ; McInerney and Donaldson [35] ; Salam [53;54] ; University of Karachi [58] ; and Naqvi et al. [37]. Sixties.

(1) The ownership of tractors, all imported, has increased rapidly since the late

${ }^{17}$ Their numbers have been estimated as follows:

$\begin{array}{ccc}\text { Year } & \text { Numbers in the Country } & \text { Numbers Imported } \\ 1968-69 & 15,600 & 4,411 \\ 1974-75 & 33,279 & 7,190 \\ 1980-81 & 98,000 & 18,923\end{array}$

These figures are from [42] and [41].
7,190
18,923 
(2) Tractors are highly concentrated on holdings of over 25 acres. They range between 33 and 55 HP, and are generally beyond the means of a vast majority of landowners.

(3) There has been almost no positive effect of use of tractors on the yield level.

(4) Tractor ownership has generally led to an increase in the size of large landholdings, both by increased landlease from poor and middle peasants and by self-cultivation by landlords.

(5) Private return on tractor is particularly high if more water is available for reclaiming land. Hiring out of tractors has also raised the return on investment, particularly as the tractor market is still highly concentrated.

(6) Cropping intensity seems to have increased on farms using tractors, but mainly where more or assured supply of water was available.

(7) While there is no conclusive evidence of net displacement of labour due to tractors, the position of sharecroppers on the landlord estates has weakened as less of their time and power of their animals is required for land preparation and postharvest operations. The traditional strength of the sharecropper, represented by his family labour and animal power, has been undermined as the landlord is now even less willing to share the benefits of new technology associated with fertilizer, water, seeds, and tractors.

The process of tractorization, dominated by large tractors (over $35 \mathrm{HP}$ ), was initiated by pressure from large landowners. It has in turn resulted in concentration of tractor ownership on the one hand and in pressure for expansion of area under large holdings both of landlords and of rich peasants, on the other. The tractor market, dependent on imports, has been closely regulated by the government. Public policy has so far consistently favoured the import and use of large tractors. In fact, a ban on import of tractors of less than $33 \mathrm{HP}$ was lifted only in mid-1982. The government has also provided handsome incentives to purchase of tractors in the form of (a) reduced import duties and taxes, and (b) A.D.B.P. loans at low rates of interest. The tax-credit subsidies have remained high even with rapidly increasing demand for tractors by large landowners. The price of imported tractors in Pakistan compares favourably with what American farmers pay in the domestic market [61].

\section{Farm Credit}

The simultaneous transformation of the peasant and feudal systems into a capitalist mode, creating capitalist farmers from among rich peasants and landlords and wage labour from among poor/middle peasants and sharecroppers, has been clearly aided by public policy and markets with unequal adoption of new technology for growth. This brings us to one of the most important elements helping the development of capitalist agriculture in Pakistan. Increasing investment in new technology - which has tended to be lumpy or indivisible - has required access to credit at reasonable cost. Poor peasants and sharecroppers have been at a particular disadvantage. The indebtedness of the peasant in poor countries is legendary, reflecting the age-old vicious circle of poverty. Most of the peasants are caught in the fetters of debt simply because their incomes are not adequate to sustain them from one season to the next. The condition of the poor peasant is often more desperate now. The cash economy is upon him and his credit-worthiness for loans from institutional sources is low. Hence his continuing dependence on traditional (highcost) sources of credit. Traditionally, poor and middle peasants have relied on friends and moneylenders, including landlords for sharecroppers. In fact, in many areas of Sind, loans advanced to sharecroppers have been an important source of strength to landlords in determining their relations, including use of labour, sharing of cost and output, etc. $[61 ; 25]$.

Institutional sources of farm credit have become quite significant in the last 20-25 years. ${ }^{18}$ However, lending practices of public institutions have clearly encouraged expenses on only certain inputs and their collateral requirements have excluded a majority of small peasants (particularly sharecroppers) from taking advantage of these loans to meet their cash needs. For instance, the A.D.B.P., which has emerged as the single most important credit agency of the government in the farm sector since the mid-Seventies, has been concentrating on loans for "lumpy" investment (tractors, tubewells, special projects, etc.), for which only large landowners (i.e. those owning or operating over 25 acres) can establish their credit. Lending for the so-called current inputs, fertilizers and seeds, has been transferred to cooperative and commercial banks, to which most small landowners are expected to turn. While these loans are soft, their acquisition by small peasants involves cumbersome procedures and a web of officials and merchants on the way. The consequent cost and delays have tended to discourage their use. data:

${ }^{18}$ The rapid expansion of credit from institutional sources can be seen in the following

$\begin{array}{crrrr}\text { Year } & \text { A.D.B.P. } & \begin{array}{c}\text { Commercial } \\ \text { Banks } \\ \text { (in million Rupees) }\end{array} & \text { Others } & \text { Total } \\ 1964-65 & 40.5 & - & 97.3 & 137.8 \\ 1969-70 & 91.3 & - & 118.8 & 201.1 \\ 1974-75 & 396.3 & 520.9 & 123.0 & 1,040.2 \\ 1979-80 & 711.6 & 1,587.4 & 716.8 & 3,015.8 \\ 1980-81 & 1,066.7 & 1,816.1 & 1,126.5 & 4,019.3\end{array}$

These figures are from Government of Pakistan $[41 ; 47]$. It should be noted that commercial banks were inducted into farm credit soon after the Bhutto government nationalized them in 1972 . Other sources are mainly the cooperative banks, which have become important
for seasonal loans since the late seventies. 
The non-institutional sources, friends (relatives) and moneylenders (merchants), thus still remain important for the poor peasants and sharecroppers. Friends and relatives cannot, of course, often be a certain and adequate source of loans which would meet one's investment requirements for profitable farming. Acquiring credit from moneylenders and merchants may be convenient, but the debt charges can easily exceed the total cost of procuring credit from institutional sources. For most poor and middle peasants, credit from these sources provides cash for consumer spending and expenses between seasons. It is often these consumer needs of the peasant, for which the institutional sources do not in any case provide loans, which maintain his dependence on money-lenders and discourage investment spending or innovation.

\section{Subsidies on Inputs}

One final aspect of public policy affecting growth and agrarian structure should now be explained. Direct subsidies on certain inputs, e.g. fertilizer, plant protection, new seeds, tubewells, have been an integral part of public policy to promote agricultural growth since the early Sixties. These subsidies should be distinguished from indirect subsidies involved in water charges, interest rates, duties and taxes on imported material and machinery, etc. We are also here not considering support prices for major crops (wheat, rice, cotton and sugarcane) which have been playing their role in changing cropping patterns, private profitability, etc. ${ }^{19}$

In Table 6, we can get an idea of the magnitude of direct subsidies on major agricultural inputs, particularly the impressive increase in the subsidy on fertilizer since the mid-Sixties. What is equally striking in these figures is that direct agricultural subsidies have claimed an increasing share of the total (capital) development expenditure of federal government, which rose from about 4-5 percent in the Sixties to over 10 percent in the late Seventies and early Eighties. It should also be pointed out that the development budget itself has increased consistently over this period: it increased eightfold between 1965 and 1982 [41]. Since we have evidence that the level and coverage of fertilizer and plant protection measures per acre are generally higher on large holdings than on small holdings, it implies a disproportionately larger flow of subsidies to owners and operators of large landholdings: see Khan [26] ; Mahmood [33]. It is similar in its effect to the unequal distribution of indirect subsidies involved in, say, the farm credit programme in the public sector. The

${ }^{19}$ Almost all of the major crops are procured by government. Farmers are guaranteed a base price which is announced some time before the crop season. The support price of a crop is supposed to reflect (a) a "fair" return to farmers, and (b) an incentive for increased productivity. However, in practice it is determined through a political process in which the interests of large landowners are well protected if not promoted. Similarly, access to procurement centres and public facilities is not equally available to producers of large and small marketable surpluses. The larger issue of the impact of subsidies, including the effects of changing input and crop prices, on agriculture in Pakistan has been recently analysed by Gotsch and Brown [16]. 
increased private profitability of new inputs is therefore quite unequal between rich peasants (or landlords) and poor (or middle) peasants. This then reinforces the tendency toward a capitalist agriculture.

\section{POLICY IMPLICATIONS AND CONCLUSION}

It would be wrong to suggest that the process of "depeasantization" in Pakistan would follow a linear path of transformation. Undoubtedly the contradictions now operating in the differentiated agrarian structure, under the influence of markets and public policy, are dissolving the dominant features of the feudal and peasant systems. However, the transformation of rich peasants (and landlords) into pure capitalists and of poor peasants (and sharecroppers) into pure wage workers can be prolonged or delayed by several countertendencies. For one thing, peasants have historically shown a high degree of resilience and ability to adapt. They could remain attached to land and provide their labour power as peasant-proletariat to the burgeoning capitalist farmers. In fact, in this they may play a complementary role for the development of a capitalist agriculture. We have at least two major arguments which need some explanation here in the light of what has been recently happening in Pakistan.

Let us first examine the landlord-tenant system. Landlords have not been entirely in favour of evicting their sharecroppers. This is partly to avoid the legal problems which a large-scale tenant eviction could produce. But the more important reasons are perhaps economic. Subsidized inputs, including tractors and other machines, have raised private profits which the landlords would not want to share with their tenants. Some landlords have adopted the policy of sharing the cost of all "modern" inputs with sharecroppers, even of those which weaken the bargaining power of tenants and make the cost of animal power high to maintain. In addition, or alternatively, landlords have expanded their self-cultivated areas, mainly by reducing the size of the parcel they give to each sharecropper. These policies increase the pool of increasingly dependent (thus relatively cheaper) labour without increased dependence on seasonal (or casual) labour, the supply of which may be uncertain or costly. This mechanism works well in areas where either there may be a chronic shortage of seasonal (wage) labour or little alternative employment opportunity exists for sharecroppers. Attached labour then provides a pool of weakened peasants, whose dependence on landlords has also been increasing due to their indebtedness.

Turning next to the peasant system, which dominates in many areas of the Punjab and the N.W.F.P., Naseem [38] reports that migration of a part of the household labour has become a desperate necessity for poor (and even middle) peasants. This migration could be to larger towns or cities within the country or even to the Middle East, which has been a major source of employment to middle (and poor) peasants. To the landless, who have not necessarily been the major beneficiaries of labour migration to the Middle East because of their poor asset position, migration from the village has been an escape from drugery for much lower wages than can be earned in industry or town. For households which own individually or jointly small parcels of land, migration from the village, particularly to large cities and the Middle East, has brought additional income for survival. The remittances have also become, at least for some middle or poor peasants, a source of additional land which can be leased or bought from other poor peasants who cannot evidently survive on their incomes in farming on small plots. An addition to one's holding could mean survival in farming, with reduced vulnerability to competition from rich peasants, or even joining the ranks of rich peasants. The peasant system at the lower end can thus extend its life-span and even remain a contending force to a rapid development of capitalist agriculture.

But this is not all. With outside income, and given the high private profitability of investment in agriculture, competition for land intensifies. An active land market can work both ways for the peasants: some middle and poor peasants can no longer survive this competition while others (some middle but most rich peasants) can flourish in an increasingly capitalist system of agriculture. In fact, the military government in Pakistan, which took power in 1977, has apparently decided to promote "corporate" farming: a decision intended to modernize agriculture in a capitalist way [48]. ${ }^{20}$ How far it extends and how rapidly it disintegrates the feudal and peasant systems will depend on the economic (and political) contradictions it creates in the society.

These tendencies reflect the contradictions which the process of development itself creates. However, their consequences for the society are enormous, particularly if public policy is used as an important instrument of change. The policy implications of our analysis of the agrarian transition in Pakistan are clear. If the intent of public policy is to promote agricultural growth within the existing agrarian structure, then the adverse social consequences of the rapid process of depeasantization should be faced.

Rapid promotion of a capitalist agriculture by deliberate state intervention normally means unequal development. This is almost inevitable with the given agrarian structure as a parameter. The bimodal policy emphasizing the growth of large (capitalist) farms will tend to increase the disparities in incomes and polarize

${ }^{20}$ There is apparently a well-orchestrated campaign to popularize the notion that largescale (corporate) farming is a panacea to agricultural growth. This argument [23] is in addition to other equally pursuasive forces increasing the involvement of industrial capitalists in corporate farming: it confers upon them direct and immediate benefits in the form of (a) agricultural subsidies (e.g. loans from A.D.B.P.), and (b) reduced taxes on industrial incomes and no tax on agricultural income as incentives for increased investment in agriculture. Of course, investment in agriculture is also a very profitable venture for those who want their "black" money laundered into legitimate income. 
the rural society. The expected trickle-down effect of such growth can be vitiateo even more if the employment effects, as expected, are alsu negative and the economy cannot expand its capacity fast enough to absorb the displaced farmers. The rhetoric for the small farmer will increasingly be confronted by a contradictory reality which public policy would have helped to create. The squeeze on the small and medium operators (owners and sharecroppers alike) will inexorably force their transformation into wage workers to be absorbed within or outside agriculture.

In order to alleviate the twin problems of income disparity and unemployment, which are the necessary consequences of a bimodal policy of agricultural development, the state must acquire an increasing proportion of new incomes created in the farm sector. The most appropriate policy instrument then is a direct tax on agricultural income. It will not only have a positive effect on agricultural productivity inducing growth, but it will at the same time transfer a part of the surplus to the society to create infrastructure, jobs, etc. for the poor. The impact of these revenues can be crucial on infrastructural investments, which are so necessary to raise agricultural production and to provide jobs and new incomes to the landless.

The softer option indicated above is premised on the assumption that the agrarian structure is not altered through direct land reforms. It is essentially a bimodal policy with sensitivity to the issues of unemployment and income disparity. However, it is not likely to slow down the process of depeasantization. This process, with its implied adverse effects on the dispossessed and the society, can be harmonized if public policy makes a dent on the very basis which creates biformity. A unimodal policy, homogenizing the effects of agricultural growth, can work only if the agrarian structure is radically restructured and a compatible delivery system is established. An egalitarian, and even efficient, delivery system for inputs, services and infrastructure in the rural areas cannot be viable without first demolishing the foundation which creates serious inequalities. Market and non-market incentives will cause these inequalities to increase even if the delivery system is apparently designed to suit the circumstances of the small peasant or farmer.

Agrarian reformism can also contribute significantly to prolonging of the process of depeasantization in a society. Populist alliances, confused with socialism, can introduce land reforms which confer upon the landless and poor peasants rights of private property on land resumed from landlords and rich peasants. Such was indeed the promise of the Bhutto regime when it launched its land reforms in 1972. ${ }^{21}$ In a country where most cultivators are either landless or possess little land, and most of the land is owned in large parcels by a small number of households, transfer of substantial land to the former groups can extend the peasant system or even transform it into a (cooperatized) family farm system.
On the other hand, a land reform programme can promote rather than retard the development of capitalist agriculture by creating the necessary pressure on landlords without redistributing a significant portion of land to landless sharecroppers and poor peasants. There is evidence that the land reforms of 1972 may have contributed to this tendency without at the same time strengthening the peasant system. Hussain [20] and Khan [29] argue that these reforms may have sharpened the contradictions in the countryside, thus hastening the process of depeasantization,

In conclusion, our analysis of classes and the agrarian transition in Pakistan attempts to demystify the process of agricultural development. We use a methodology which not only emphasizes the highly differentiated nature of the agrarian structure, but also identifies classes based on unequal endowments of land and labour. The proposed typology, with supporting empirical evidence, highlights the asymmetry of relations among the various classes. Further, this study traces the agrarian transition under way in Pakistan, with emphasis on the sources and the consequent process of depeasantization. We have particularly focussed on those elements of public policy which may have helped to hasten the process and sharpen the class differences. Finally, we have briefly presented alternative policy options to minimize and even avoid the adverse social consequences which are likely to follow from the capitalist transition of agriculture in Pakistan.

${ }^{21}$ These claims were highly exaggerated $[29$, Chapter 5$]$. 


\section{Appendix}

\section{Background of the Land Tenure Systems}

Historically, the areas which now constitute Pakistan, peasants (cultivators) had no right to own land before the British conquest of India. In the pre-British days, even after the decay of the Mughal Empire in India, there were two basic claims on land: production by peasants and collection of rent (as land tax) by the King's servants for the absolutist state. The direct producers on land were tenants and the state (or the kind) was their landlord. Admittedly this relationship had been greatly disturbed in many areas of India owing to the disintegration of the Mughal rule by about the mid-18th century. Simultaneous and contending claims on land had become quite common, although no clear market for land had yet developed. Rent as income from private ownership of land was not an established economic relationship. In fact, this issue has been debated quite extensively in the literature on the pre-British agrarian system in India and Pakistan. We have found the relevant material in Habib [17] ; Alavi [3] ; Khan [29] and Hamid [18].

The idea of private (rental) property of land was transplanted into India after conquest by the British. Starting from Bengal in the 1790s, private titles to land were awarded to the former rent collectors and collaborators. These included some of the former ruling chiefs, as the Mirs (or amirs) of Sind were allowed to retain a large part of their former estates after 1843 . Similarly, most of the traditionally cultivated area in the Punjab was alloted to a small number of large landowners after 1849 [18]. Initially, most of the land was distributed as private property to a limited number of former rent collectors and "friends" and the direct producers (peasants) continued to remain tenants, now of the new (private) landlords. Landlords were content with collection of rent from their tenants in the face of shortage of labour and tenants had nowhere else to go to earn their incomes. This became the basis of the feudal system which has existed in Pakistan.

There was one significant change introduced by the British with the development of a canal irrigation system in the Punjab in the 1880s. Crown lands, which could not be cultivated earlier without assured supply of water, were distributed to landless cultivating peasants in small parcels in the so-called canal colony districts. This was seen as the beginning of yeomen farmers, supporting the British in their task of transferring surplus from the colony. But before the end of the 19th century, a large proportion of these family farmers started to lose their lands to money-lenders. Land fragmentation became another debilitating factor, particularly because of the growth of population and Muslim laws of inheritance. In 1901, the British administration introduced legislation in the Punjab and the N.W.F.P. to protect the peasantry from land alienation and fragmentation. However, it did not completely halt the process of depeasantization or the increased vulnerability of these farmers to the forces of the market $[29 ; 18]$. A peasant system on a similar scale never developed in Sind, mainly because of the absence of a perennial irrigation system. In fact, even after the construction of Lloyd (now called Sukkur) Barrage in 1932, most of the land remained concentrated in the hands of a small number of landlords and cultivated by tenants-at-will (haris) [29]. This in short is a historical background of the agrarian systems of Pakistan.

\section{REFERENCES}

1. Agricultural Development Bank of Pakistan. A.D.B.P. Yearbook 1980-81. Islamabad. 1982.

2. Ahmad, B. Farm Mechanization and Agricultural Development: A Case Study of Pakistan. Michigan State University. Ph.D. Dissertation. 1972.

3. Alavi, H. "India: Transition from Feudalism to Colonial Capitalism". Journal of Contemporary Asia. Vol. 10, No. 4. 1980.

4. Alavi, H. "The Rural Elite and Agricultural Development in Pakistan". Pakistan Economic and Social Review. Vol. 14, Nos. 1-4. 1976.

5. Bardhan, P. "Agrarian Class Formation in India". Journal of Peasant Studies. Vol. 10, No. 1. 1982.

6. Berry, R. A. and W. R. Cline. Agrarian Structure and Productivity in Developing Countries. Baltimore: Johns Hopkins University Press. 1979.

7. Bose, S. R. and E. H. Clark II. "Some Basic Considerations on Agricultural Mechanization in Pakistan”. Pakistan Development Review. Vol. IX, No. 3. Autumn 1969

8. Burki, S. J. "The Development of Pakistan's Agriculture: An Interdisciplinary Explanation". In R. D. Stevens and Others (eds.), Rural Development in Bangladesh and Pakistan. Honolulu: University of Hawaii Press. 1976.

9. Currie, J. M. The Economic Theory of Agricultural Land Tenure. Cambridge: Cambridge University Press. 1981.

10. Eckert, J. B. "Private Tubewell Numbers in Pakistan: A Synthesis". Pakistan Development Review. Vol. XIII, No. 1. Spring 1974

11. Eckert, J. B. "Rural Labour in the Punjab". Lahore: Punjab Planning and Development Department. 1972. (Unpublished)

12. Emmanuel, A. Unequal Exchange. New York: Monthly Review Press. 1972.

13. Esso Pakistan Fertilizer Co. Ltd. "Pakistan Fertilizer Demand Forecast Study". Karachi. 1978. (Unpublished)

14. Falcon, W. P. and C. H. Gotsch. "Agriculture in Pakistan: An Analysis of Past Progress and Future Prospects". Karachi: Pakistan Institute of Development Economics. 1964. (Unpublished) 
15. Gotsch, G. H. "Tractor Mechanization and Rural Development in Pakistan". International Labour Review. Vol. 107, No. 2. 1973.

16. Gotsch, C. H. and G. Brown. Prices, Taxes and Subsidies in Pakistan Agriculture, 1960-1976. Washington, D.C.: World Bank. 1980. (World Bank Staff Working Paper No. 387)

17. Habib, I. The Agrarian System of Mughal India, 1556-1707. New York: Asia Publishing House. 1963.

18. Hamid, N. "Dispossession and Differentiation of the Peasantry in the Punjab During the Colonial Rule". Journal of Peasant Studies. Vol. 10, No. 1. 1982.

19. Hussain, A., and K. Tribe. Marxism and the Agrarian Transition. Two Volumes. London: Macmillan. 1981.

20. Hussain, S. Akmal. "The Impact of Agricultural Growth on the Agrarian Structure of Pakistan, with Special Reference to the Punjab Province: 1960 to 1978 ". Ph.D. Dissertation, University of Sussex. 1980.

21. Hussain, S. Akmal. "Technical Change and Social Polarization in Rural Punjab". In K. Ali (ed.), Pakistan: The Political Economy of Rural Development, Lahore: Vanguard Books. 1982.

22. Johnston, B.F., and P. Kilby. Agriculture and Structural Transformation. New York: Oxford University Press. 1975.

23. Khan, Abdul Jabbar. "Increasing Agricultural Production". Pakistan Agriculture. Vol. 5, No. 1. 1983.

24. Khan, Dilawar A. "Employment and Occupational Change in the Rural Punjab: Consequences of Green Revolution". Lahore: Economic Research Institute. 1978. (Unpublished)

25. Khan, M. H. "Agriculture in Sind: A Report to Sind Regional Plan Organisation". Karachi. 1982. (Unpublished)

26. Khan, M. H. The Economics of the Green Revolution in Pakistan. New York: Praeger Publishers. 1975.

27. Khan, M. H. "Farm Size and Productivity Relationships in Pakistan". Pakistan Development Review. Vol. XVIII, No. 1. Spring 1979.

28. Khan, M. H. "The Political Economy of Agricultural Research in Pakistan". Pakistan Development Review. Vol. XX No. 2. Summer 1981.

29. Khan, M. H. Underdevelopment and Agrarian Structure in Pakistan. Boulder, Colorado: Westview Press. 1981.

30. Lehmann, D. "After Chayanov and Lenin". Journal of Development Economics. Vol. 11, No. 2. 1982.

31. Lenin, V. I. The Development of Capitalism in Russia. Second Edition. Moscow: Progress Publishers. 1964.
32. Lewis, W. A. The Evolution of the New International Economic Order. Princeton: Princeton University Press. 1978.

33. Mahmood, M. "The Pattern of Adoption of Green Revolution Technology and Its Effects on Land Holdings in the Punjab". Pakistan Economic and Social Review. Vol. 15, Nos. 1-2. 1977.

34. Mahmood, M., and Nadeem-ul-Haque. "Farm Size and Productivity Revisited". Pakistan Development Review. Vol. XX No. 2. Summer 1981.

35. McInerney, J. P., and G. P. Donaldson. The Consequences of Farm Tractors in Pakistan. Washington, D.C.: World Bank. 1975. (World Bank Staff Working Paper No. 210)

36. Mohammad, G. "Private Tubewell Development and Cropping Patterns in West Pakistan". Pakistan Development Review. Vol. V. No. 1. Spring 1965.

37. Naqvi, Syed Nawab Haider, Ashfaque H. Khan, Nasir M. Khilji, Ather Maqsood Ahmed, and Associates. The P.I.D.E. Macro-econometric Model of Pakistan's Economy (Vol. I). Islamabad: Pakistan Institute of Development Economics. 1983.

38. Naseem, S. M. Underdevelopment, Poverty and Inequality in Pakistan. Lahore: Vanguard Books. 1981.

39. Pakistan. Land Reforms Commission. Report of the Land Reforms Commission for West Pakistan. Lahore. 1959.

40. Pakistan. Ministry of Agriculture and Works. Report of the Farm Mechanization Committee. Islamabad. 1970.

41. Pakistan. Ministry of Finance. Pakistan Economic Survey 1981-82. Islamabad. 1982.

42. Pakistan. Ministry of Food and Agriculture. Agricultural Statistics of Pakistan 1980. Islamabad. 1981.

43. Pakistan. Ministry of Food and Agriculture. Report of the Pakistan Agricultural Inquiry Committee, 1951-52. Karachi. 1952.

44. Pakistan. Ministry of Food and Agriculture. Report of the Pakistan Food and Agriculture Commission 1960. Karachi. 1960.

45. Pakistan. Ministry of Food and Agriculture. Agricultural Census Organization. Pakistan Census of Agriculture 1972. Vol. I. Lahore. 1976.

46. Pakistan. Ministry of Food and Agriculture. Agricultural Census Organization. Pakistan Census of Agricultural Machinery 1975 (Final Report). Lahore. 1977.

47. Pakistan. Planning Commission. The Fifth Five Year Plan 1978-83, Sectoral Programmes (Part II). Islamabad. 1978.

48. Pakistan. President's Secretariat. Land Reform (Amendment) Ordinance 1981 (Ordinance No. XLVII of 1981). Islamabad.1981.

49. Pakistan. Statistics Division. Pakistan Census of Agriculture 1980, Preliminary Report. Lahore. 1983. 
50. Pakistan Muslim League. Report of the Agrarian Committee. Karachi. 1949.

51. Punjab. Bureau of Statistics. Punjab Development Statistics 1980. Lahore. 1981.

52. Salam, A. "Factor Inputs Use and Factor Productivity on Different Farm Categories in the Punjab". Pakistan Development Review. Vol. XVII, No. 3. Autumn 1978.

53. Salam, A. "Farm Tractorization, Fertilizer Use and Productivity of Mexican Wheat in Pakistan". Pakistan Development Review. Vol. XX, No. 3. Autumn 1981.

54. Salam, A. "Technological Change, Tenant Displacement and Adjustment in

Pakistan: Some Preliminary Observations". Pakistan Development Review. Vol. XVI, No. 4. Winter 1977.

55. Sind. Hari Enquiry Committee. Hari Enquiry Committee: Minute of Dissent by M. Masud. Karachi. 1949.

56. Sind. Hari Enquiry Committee. Report of the Government Hari Enquiry Committee 1947-48. Karachi. 1948.

57. Sind. Tenancy Legislation Committee. Report of the Tenancy Legislation Committee. Karachi. 1945.

58. University of Karachi. Applied Economics Research Centre. "Impact of Tractors on Agriculture in Pakistan”. Karachi. 1982. (A Study for A.D.B.P.; Unpublished)

59. USAID. The On-Farm Water Management Project in Pakistan. Washington, D.C. 1982. (A.I.D. Project Evaluation Report No. 35)

60. World Bank. "Pakistan: Development, Issues and Policies". Vol. I. Washington, D.C. 1978. (Unpublished)

61. World Bank. Pakistan Staff Appraisal Report: Fifth Credit for the Agricultural Development Bank. Washington, D.C. 1979.

62. World Bank. Staff Appraisal Report: Pakistan On-Farm Water Management Project. Washington, D.C. 1981.

63. Yasin, C. G. "Private Tubewells in the Punjab". Lahore: Punjab Board of Economic Inquiry. 1975. (Unpublished) 